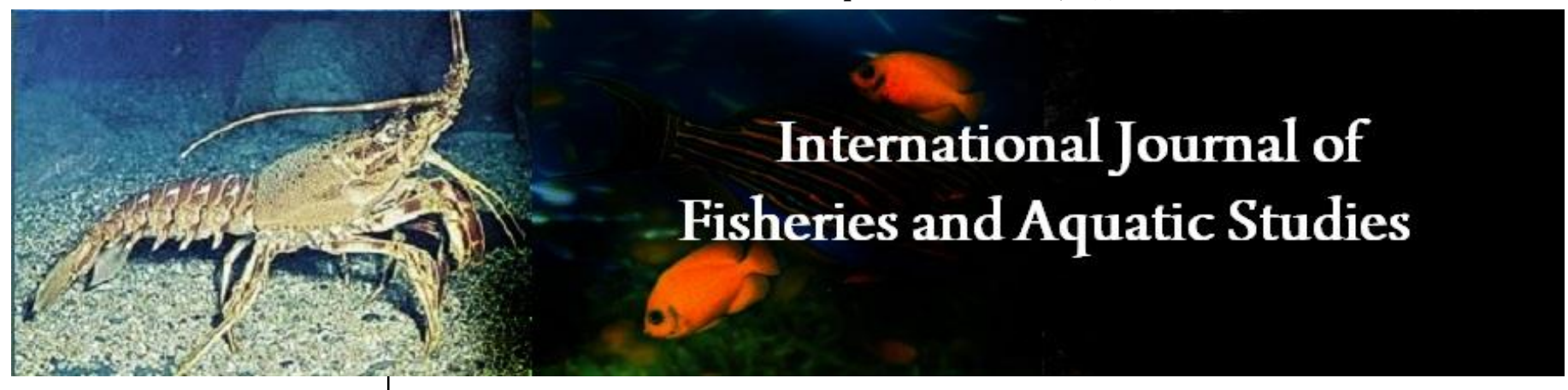

E-ISSN: 2347-5129

P-ISSN: 2394-0506

(ICV-Poland) Impact Value: 5.62

(GIF) Impact Factor: 0.549

IJFAS 2021; 9(4): 332-340

(C) 2021 IJFAS

www.fisheriesjournal.com

Received: 25-05-2021

Accepted: 27-06-2021

Rene Paul Njock Ndômbôl

Ecosystems and Fisheries Resources

Laboratory, Institute of Fisheries and

Aquatic Sciences of The University of

Douala at Yabassi, Po Box 7236-

Douala, Cameroon

Mathieu Ndomou

Department of Biochemistry,

Laboratory of Food Sciences and

Nutrition, Faculty of Sciences,

University of Douala, Po Box 24157

Douala, Cameroon

Huguette Lesly Djeuachi Tchuitcheu Ecosystems And Fisheries Resources Laboratory, Institute of Fisheries and Aquatic Sciences of the University of Douala at Yabassi, Po Box 7236Douala, Cameroon

Calvin Bogning Zangueu Laboratory of Animal Biology, Faculty of Sciences, University of Douala, Po Box 24157 Douala, Cameroon

Merlin Nchoutpouen Ngafon Laboratory of Food Sciences and Nutrition, Faculty of Sciences, University of Douala, Po Box 24157 Douala, Cameroon

Jean Valery François Nsoga Laboratory of Food Sciences and Nutrition, Faculty of Sciences, University of Douala, Po Box 24157 Douala, Cameroon

Jules Christophe Manz Laboratory of Food Sciences and Nutrition, Faculty of Sciences,

University of Douala, Po Box 24157

Douala, Cameroon

François Tchoumbougnang Ecosystems and fisheries resources laboratory, Institute of Fisheries and Aquatic Sciences of the University of Douala at Yabassi, Po Box 7236Douala, Cameroon

Corresponding Author:

Mathieu Ndomou

Department of Biochemistry,

Laboratory of Food Sciences and

Nutrition, Faculty of Sciences,

University of Douala, Po Box 24157

Douala, Cameroon

\section{Assessment of fish by-products in market environment of Douala and determination of their nutritional value}

\author{
Rene Paul Njock Ndômbôl, Mathieu Ndomou, Huguette Lesly Djeuachi \\ Tchuitcheu, Calvin Bogning Zangueu, Merlin Nchoutpouen Ngafon, Jean \\ Valery François Nsoga, Jules Christophe Manz and François \\ Tchoumbougnang
}

DOI: $\underline{\text { https://doi.org/10.22271/fish.2021.v9.i4d.2553 }}$

\section{Abstract}

To assess the fish by-products released, we surveyed 158 fish pre-caterers and 33 structures in 12 markets in Douala. A random sample of these by-products was used for bromatological analysis. Oils extracted from these samples were characterized by determining some chemical indexes. Investigation showed more than 238 tons of by-products are annually released into the environment of the observed markets. Flour Analysis of by-products showed a moisture content of $22.04 \pm 0.03 \%, 50.29 \pm 0.02 \%$ proteins, $29.03 \pm 0.15 \%$ ash, $20.3 \pm 0.03 \%$ lipids, $0.37 \pm 0.15 \%$ total carbohydrates, and mineral elements such as calcium $(6.08 \pm 0.002 \mathrm{~g} / \mathrm{kg})$, phosphorus $(7.093 \pm 0.003 \mathrm{~g} / \mathrm{kg})$, and iron $(328 \pm 2.65$ $\mathrm{mg} / \mathrm{kg}$ ). Analyses of chemical indexes of the oil extracted showed that they were within the range of Codex Alimentarius standard values. It can be concluded that Douala market's fish by-products are of good nutritional quality and could therefore be used in animal nutrition.

Keywords: fish pre-caterers, fish by-products, damaged fish, nutritional value

\section{Introduction}

Recent trends around the world point to a decline in landings from capture fisheries, indicating that fish stocks have reached or even exceeded the point of maximum yield ${ }^{[1]}$. Faced with this situation, aquaculture becomes the only viable alternative for increasing fish production in order to meet the protein needs of the world population. Aquaculture, possibly the steadily and rapidly growing food production sector, currently provides almost $50 \%$ of the fish consumed worldwide. This sector of activity is therefore considered to have the greatest potential to meet the growing demand for aquatic food ${ }^{[2]}$. However, although aquaculture is a solution, the fact remains that it presents certain limitations because of many difficulties, including feeding the species to be reared. In the case of fish farming, fish require a high protein intake for their growth. Fishmeal is generally the major component of feed in aquaculture, but its high purchase price has directed research towards alternative sources of protein. In addition, using fishmeal and fish oil from wild fish (minority fishing) to produce farmed fish has been a subject of strong controversy for many years ${ }^{[3]}$. In a somewhat schematic way, we can say that we produce fish with fish. Even though fish are good suppliers of ingested protein, it will readily be agreed upon that the primary objective must be the production of quality animal protein for human nutrition from other protein sources. The yield of fishmeal catches varies from 20 to $25 \%$ and the yield of fish oil varies from 5 to $12 \%{ }^{[4]}$. This poses a real problem in the face of the objective of food security for the less well-off local populations, and in terms of employment, the processing sector of the same products targeted by the milling industry is already a source of many jobs, particularly for women ${ }^{[3]}$. In order to preserve natural resources while allowing a sustainable development of aquaculture, it is therefore imperative to use other types of raw materials. Global fish consumption generates a significant amount of by-products in the form of heads, guts, bones, tails, fins and skins which are left in the wild or in garbage cans. These fish wastes are excellent sources of protein, fat and minerals. The discharge of such wastes represents a major environmental problem because of their high moisture content and unpleasant odor ${ }^{[5]}$. 
In Cameroon, to the extent of our knowledge, no study has been carried out on the assessment of these by-products released into the market environment, yet they have a very high nutritional value. The objective of this study is to make an assessment of the typology and quantity of fish byproducts released in to the environment of the city of Douala and to determine their nutritional value.

\section{Material and Methods}

Two types of fish by-products were used for this study. Fish pre-treatment by-products and spoiled fish from the markets. Fishmongers and warehouses in the city of Douala were also included in the study. Two surveys were carried out simultaneously in the city, the main objectives were to identify the fate of the fish by-products. Twelve (12) markets in the city were visited namely Youpwé, New-bell, "Grand Hangar", Essengue, New-Deido, Sandaga, Saker, Bonaberi "Grand Hangar", Bonaberi "Bonassama", Akwa Nord, Bonamoussadi and Cite de Palmier. Two questionnaires were used, the first which provided information on the actors, cleaning practices, the type of pre-treated by-product, the quantities and fate of by-products in the markets and the second, which provided information on the types of factories, the quantity of damaged products and their fates. Because of their proximity to the laboratory, the organization of the actors and the accessibility to by-products, Youpwé and Newbell "Grand Hangar" were used for the evaluation of the quantity of pre-treated by-products. By-products of each market were weighed daily for a period of 21 days using an electronic scale (Diamond brand, capacity $40 \mathrm{~kg} \pm 5 \mathrm{~g}$ ). During this period, samples of by-products collected randomly were dried in an oven at $55^{\circ} \mathrm{C}$ for an average time of 15 hours. The dried by-products were crushed with a blender processor until a yellow powder was obtained. Contents of moisture, ash, minerals $(\mathrm{Ca}, \mathrm{Mg}, \mathrm{K}, \mathrm{Na}, \mathrm{P}, \mathrm{Zn}, \mathrm{Cu}, \mathrm{Mn}$ and $\mathrm{Fe})$, total proteins (Kjeldahl method) were determined by AOAC methods ${ }^{[6]}$ and total carbohydrates was claculated by the method of difference. Lipid contents were determined by Soxhlet method ${ }^{[7]}$. Lipid was characterized by determination of its peroxide, anisidine, acid and iodine indexes ${ }^{[8]}$, and total oxidation ${ }^{[9]}$. Statistical analysis of the results was done using Microsoft Excel 2013 and SphinxPlus.V5.TuiTe software.

\section{Results and Discussion}

3.1.1 Assessment of types and quantities of fish byproducts

\subsubsection{Pre-treatment and by-products}

\subsection{Actors}

The survey was carried out in 12 markets of the city of Douala. 158 fish pre-caterers were identified and questioned. This activity was shown to be carried out only by Cameroonians, and was highly dominated by males (98.7\%) against $1.3 \%$ female. Christians were predominant $(78.5 \%)$, followed by muslims $(8.9 \%)$ and others religions $(12.7 \%)$. Figure 1 show the percentage of pre-caterers according to their nationality, gender and religion.

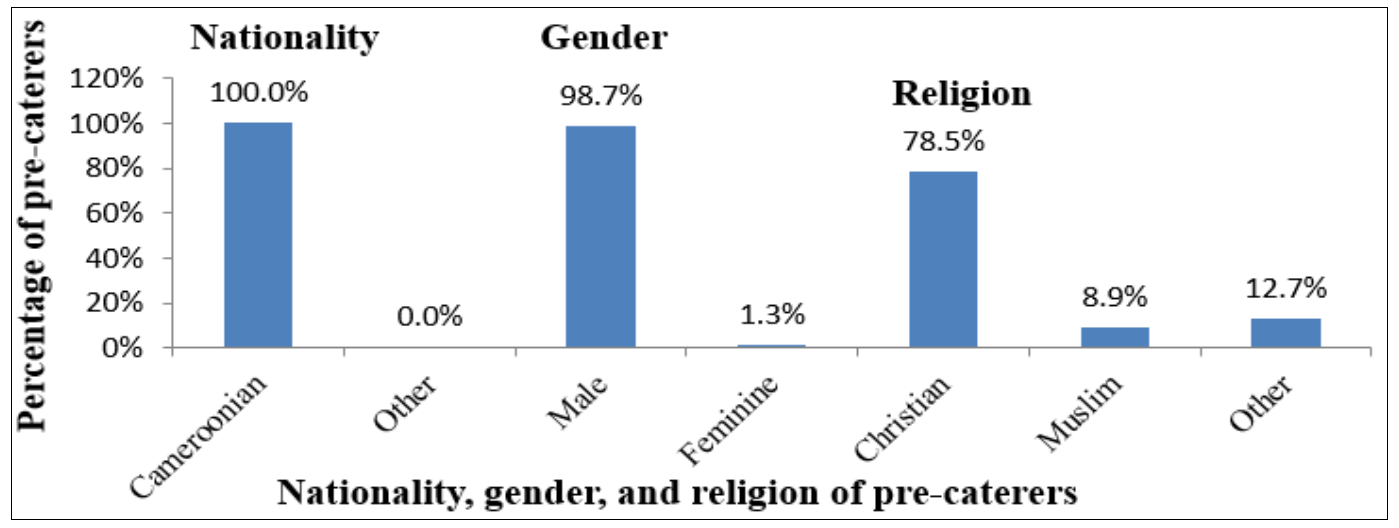

Fig 1: Percentage of pre-caterers according to their nationality, gender and religion

Young adults (20 to 40 years old) were more present in the market environment $(84.8 \%)$ than older people $(2.5 \%)$. Many were high school drop-outs $(57 \%)$ and $1.3 \%$ were illiterate. Matrimonial status consisted of $36.7 \%$ single, $29.1 \%$ married and $1.3 \%$ widowers. Figure 2 shows the percentage of precaterers according to their age, educational level, and marital status.

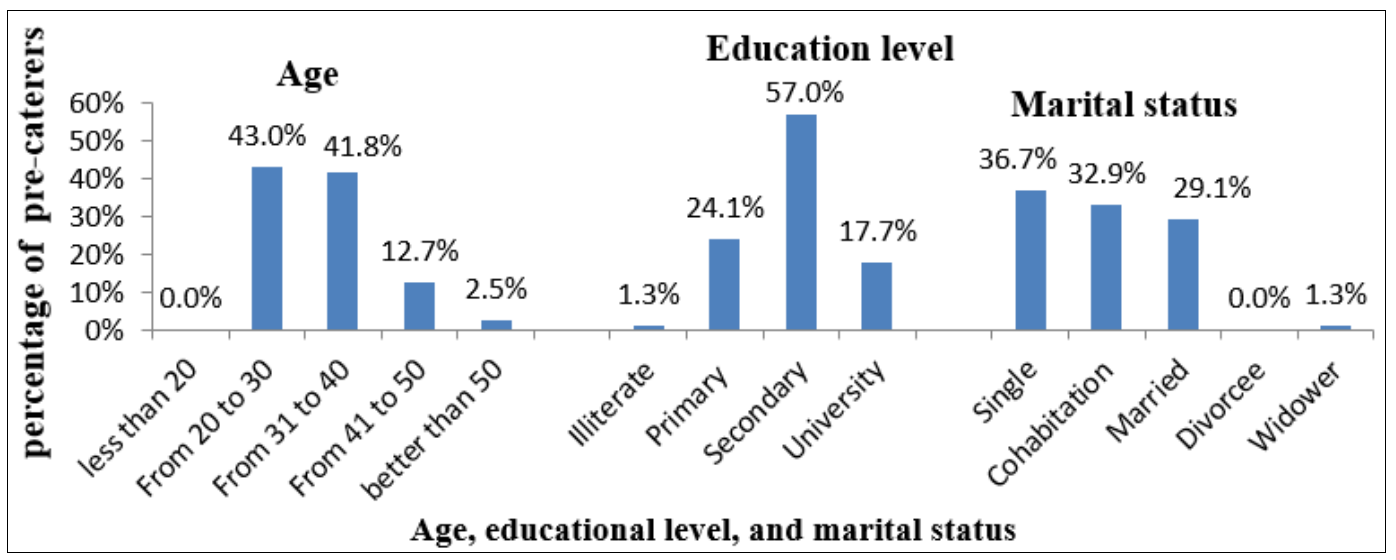

Fig 2: Percentage of pre-caterers according to their age, educational level, and marital status 
Amongst these individuals $67.1 \%$ practiced pre-treatment of fish as a main occupation against $32.9 \%$ who did it as a temporary or secondary occupation. $53.2 \%$ did not have a secondary job, $35.4 \%$ worked in the informal sector highly dominated by fish dealers and deliverers in restaurants, hotels and individual homes. We also found that $3.8 \%$ worked in the formal sector strongly represented by teachers, security guards, $6.3 \%$ students and some pupils (1.3\%). Figure 3 shows the percentage of pre-caterers according to the perception of the profession of fish pre-caterers.

RAS: Unique profession exercised; A: Informal sector; B: Formal sector

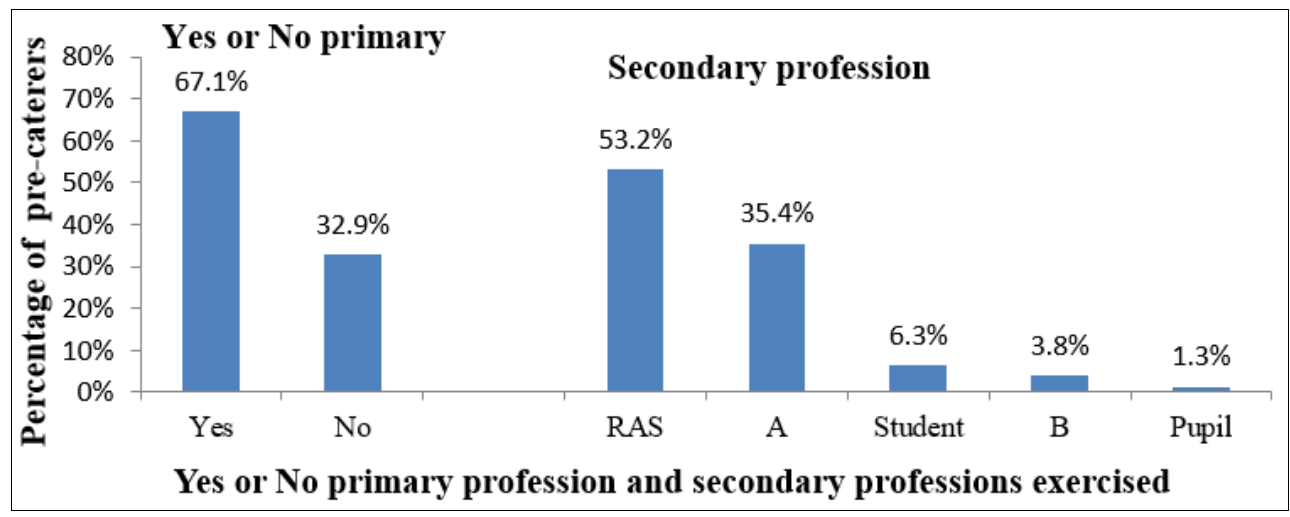

Fig 3: Percentage of pre-caterers according to the perception of the profession of fish pre-caterers.

\subsection{Typology and fate of fish pre-treatment by-} products

Amongst the fish by-products produced in these markets, scales were always present $(100 \%)$ followed by viscera, gills
(97.5\%) and heads $(94.9 \%)$. Figure 4 shows the percentage of pre-caterers based on the probability of the presence of a type of fish by-product in these markets.

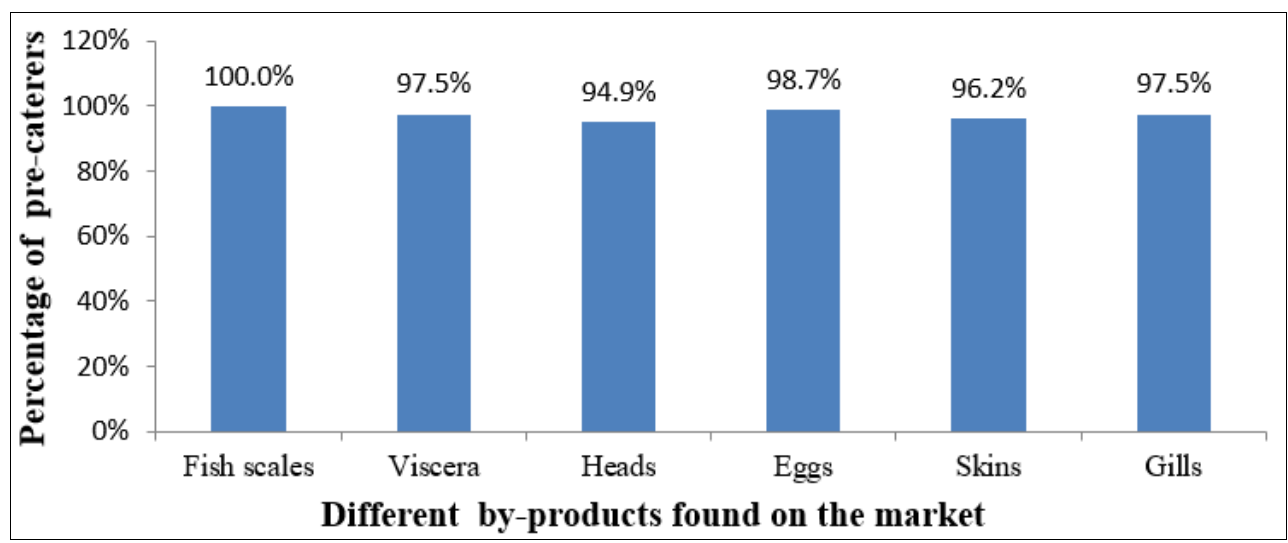

Fig 4: Percentage of pre-caterers based on the probability of the presence of a type of fish by-product in these markets Some by-products are valuable in these markets, and they are shown in Table I.

Table 1: The different by-products valued in these markets

\begin{tabular}{|c|c|c|c|c|c|}
\hline By-products & Sold & Consumed & Used & Sale price & Purpose \\
\hline Swin Bladder & $\mathrm{X}$ & & & $\begin{array}{l}80 \text { to } 210 \text { thousand CFA } \\
\text { francs per } \mathrm{kg}\end{array}$ & $\begin{array}{l}\text { To produce sutures and objects in } \\
\text { medicine and purchased by nigerians }\end{array}$ \\
\hline Gills & $X$ & $X$ & & 5000 FCFA the $10 \mathrm{~L}$ bucket & For marine mammal fishing \\
\hline Bibs & $\mathrm{X}$ & $\mathrm{X}$ & & \multirow{3}{*}{100 to $2000 \mathrm{FCFA}$} & \multirow{2}{*}{ To housewives and Chinese } \\
\hline Hoses & $\mathrm{X}$ & $X$ & & & \\
\hline Egg & $\mathrm{X}$ & $\mathrm{X}$ & $\mathrm{X}$ & & \multirow{2}{*}{ For treatments or rituals } \\
\hline Heart & $\mathrm{X}$ & $\mathrm{X}$ & $\mathrm{X}$ & 500 FCFA & \\
\hline Carcass (skins, heads, and stops) & $\mathrm{X}$ & $X$ & & 2000 to 15000 FCFA & To housewives or fish sellers \\
\hline
\end{tabular}

As shown in table I, the quantity to price ratio of bibs, casings, eggs, hearts and carcasses is highly different.

Swim bladder sizes ranged from smallest to largest depending on the size of the fish. The most popular came from Polydactylus quadrifilis and Pseudotolithus spp. Bibs are located along the abdomen of Pseudotolithus spp. Casings from large fish were mixtures of lungs, stomach and long intestines that were bought by chinese and housewives from the fish pre-processors in new-bell market.
Swim bladders and carcasses were the two types of byproducts regularly sold or consumed in these markets. As for the other by-products, the sales are done according to customer needs. Regardless of the value of the by-products in these markets, there is always an important amount of waste poured into the environment because the collection of byproducts in these markets is done by sorting.

Figure 5 shows the percentage of pre-caterers according to the perception of the fate, exploitation, selling price and 
recipients of fish by-products. The predominant fate $(43 \%)$ of fish byproducts in these markets was throwing, selling and eating. At least $16.5 \%$ released by-products into the environment. Nearly $60.8 \%$ did selling after sorting against $22.8 \%$ who sold the entire products Figure 5 shows the percentage of pre-caterers according to the perception.

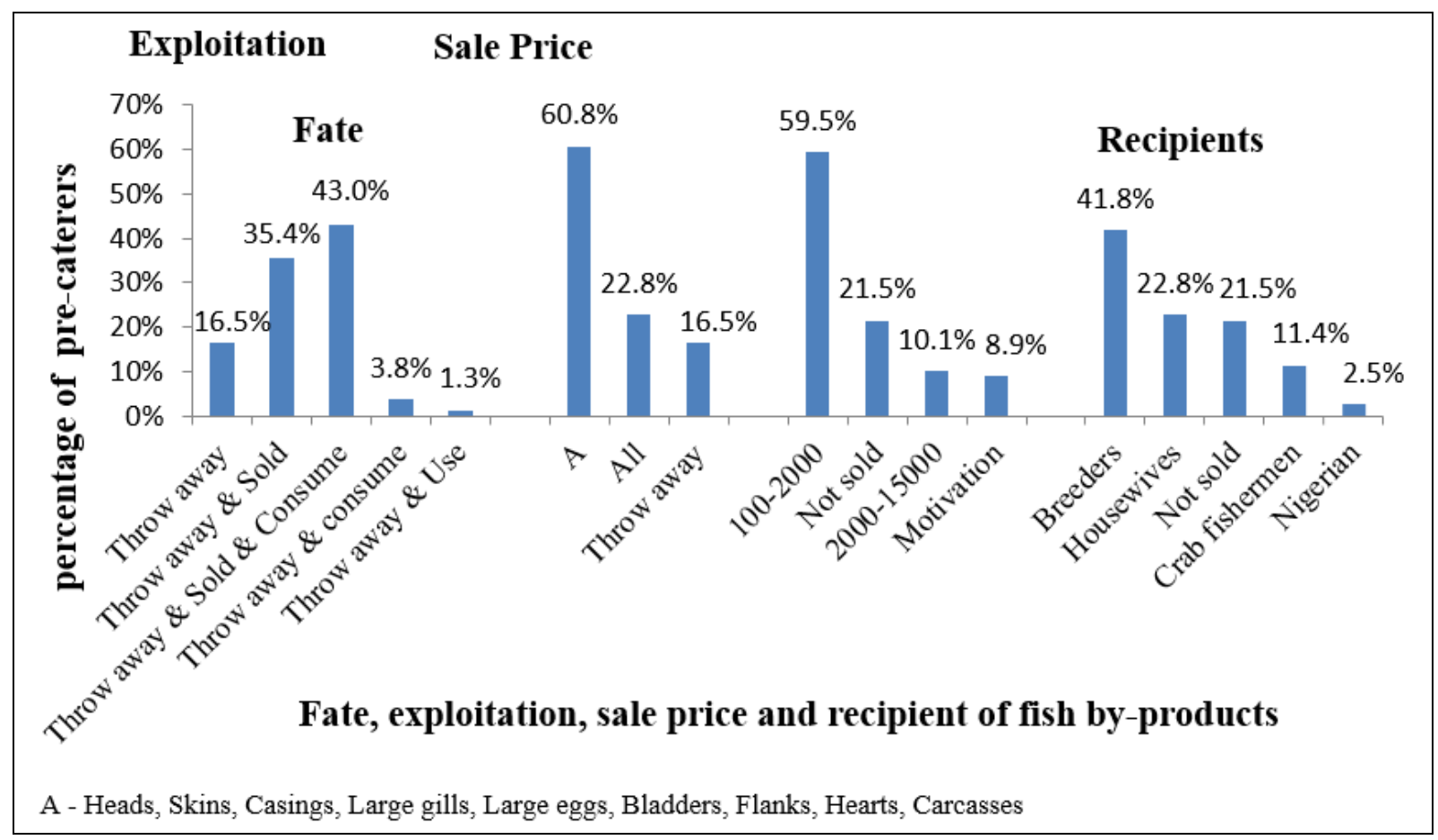

Fig 5: Percentage of pre-caterers according to the perception of the fate, exploitation, sale price, and recipients of these fish by-products

\subsection{Quantity of by-products}

We found that about $13.16 \pm 12.28 \mathrm{~kg}$ of by-products were generated by each pre-processor per day and $40.5 \%$ produce less than $10 \mathrm{~kg} /$ day. Only $2.5 \%$ produced more than 50 $\mathrm{kg} /$ day. Figure 6 shows the percentage of pre-caterers based on the amount of fish by-products produced per day.

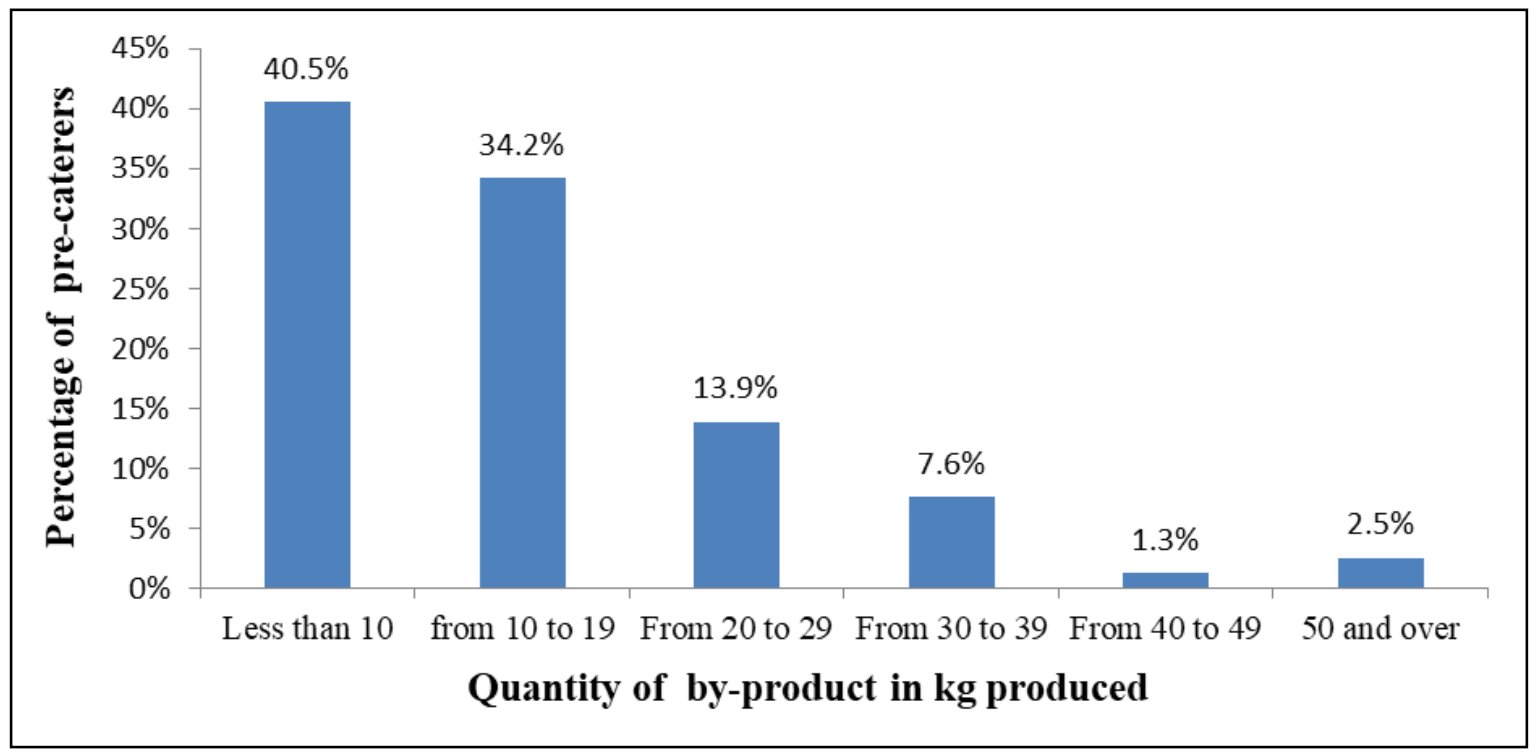

Fig 6: Percentage of pre-caterers based on the amount of fish by-product produced per day

The differences between individuals depend on the seniority of pre-caterers and their confidence towards clients. Senior master fishing processing technics such as filleting and trimming? So some customers choose pre-caterers based on the quality of cleaning, the ability to detect fish of good quality and the rate of home services. Results of by-product weighings are shown in Table II.

Table 2: Average value (kilograms) of by-products collected per day in two markets of Douala city

\begin{tabular}{|c|c|c|c|}
\hline & Average waste In kg & Average of co-products In kg & Total by-products In kg \\
\hline Youpwe market & $63.85 \pm 24.23$ & $26.25 \pm 10.37$ & $90.09 \pm 34.59$ \\
\hline Central market & $121.37 \pm 24.64$ & $24.64 \pm 7.12$ & $146.01 \pm 44.28$ \\
\hline
\end{tabular}

Each value is the mean \pm standard deviation $(\mathrm{n}=21$ days $)$ 
By-products are mainly recovered by cattle breeders, but due to the lack of conservative methods, purchase of these products is irregular. Housewives also collect it for domestic consumption, fishermen for fishing activities. Nigerian traders use bladders to make surgery sutures. Heart and fat are used in traditional medicine.
3.1.1.1.4 Quantitative estimate of by-products released into the environment of the markets

The average daily waste produced by each fish pre-caterer was $13.16 \pm 12.28 \mathrm{~kg}$. At least $16.5 \%(\mathrm{n}=158)$ dumped their by-products in the environment. The average waste weight for the two markets is shown in table III.

Table 3: Quantitative estimation of fish by-products released into the environment of the markets

\begin{tabular}{|c|c|c|c|c|c|c|}
\hline \multirow{2}{*}{} & \multicolumn{2}{|c|}{ Day/T } & \multicolumn{2}{c|}{ Month/T } & \multicolumn{2}{c|}{ Year/T } \\
\cline { 2 - 7 } & Min & Max & Min & Max & Min & Max \\
\hline Surveys & 0.023 & 0.663 & 0.688 & 19.897 & 8.259 & 238.759 \\
\hline Youpwe market & 0.039 & 0.088 & 1.188 & 2.642 & 14.263 & 31.709 \\
\hline Central market & 0.096 & 0.146 & 2.902 & 4.380 & 34.823 & 52.564 \\
\hline
\end{tabular}

Over 8 to 238 tons of by-products are released into the environment each year. At Youpwe market up to 31 tons of fish waste and over 52 tons at New-Bell market were released into the environment each year.

\subsubsection{Damaged fish}

3.1.1.2.1 Presentation of the prospected sites

Thirty-three (33) companies were visited for the study namely fish shops, supermarkets, and warehouses opened between 1990 and 2018.

Most of the people (72.73\%) purchased fish daily and $9.09 \%$ each three months. Meanwhile fish wastes are produced throughout the year with a monthly percentage of $36.36 \%$. Figure 7 is the frequency of fish supply and occurrence of damaged fish in the structures surveyed.

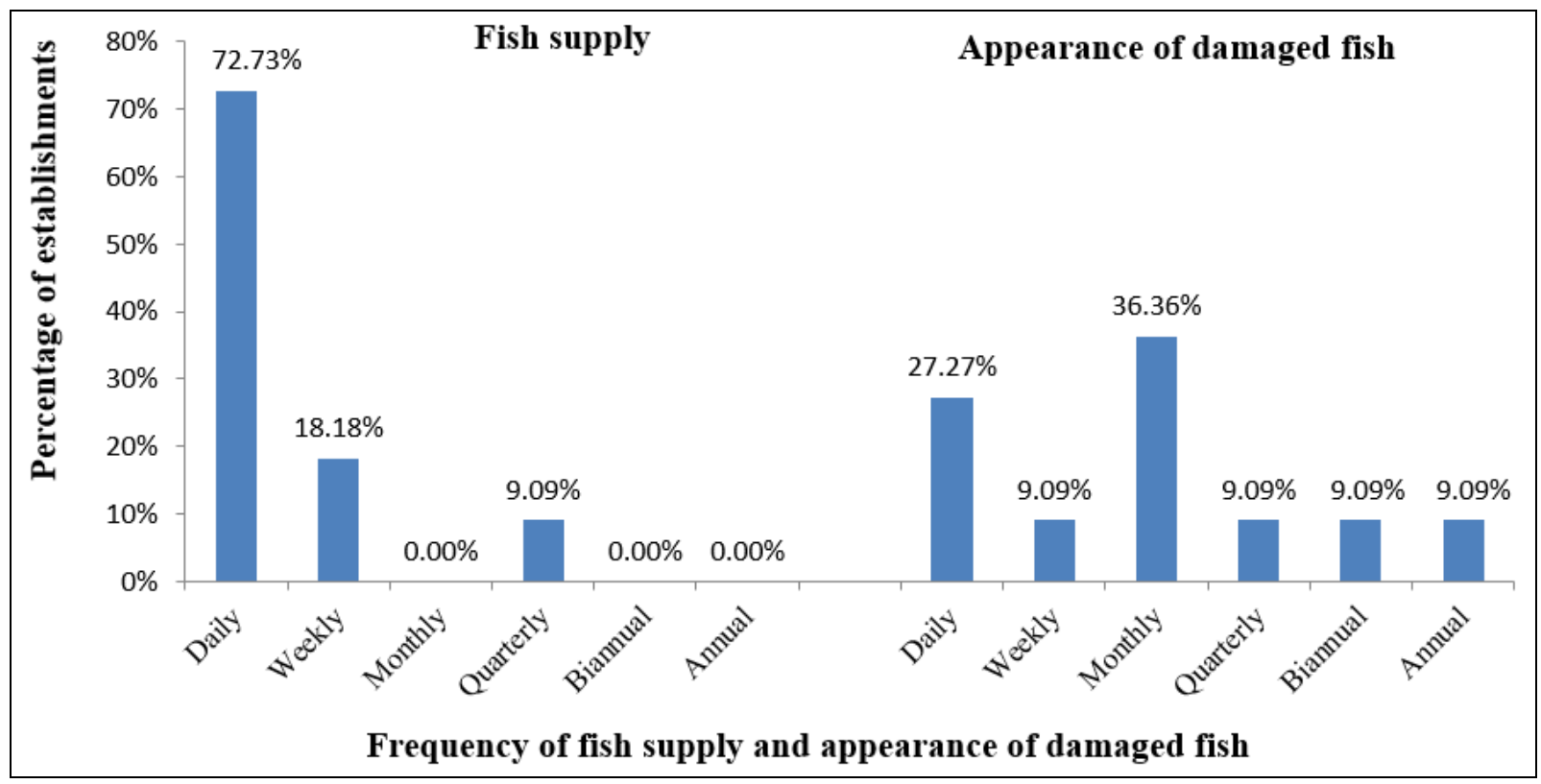

Fig 7: Frequency of fish supply and occurrence of damaged fish in the structures surveyed

Amount of fish supply ranged from $35 \mathrm{~kg}$ to 1.500 tons per day and the quantity of waste released per year varied from 0.5 to $2000 \mathrm{~kg}$ with $63.64 \%$ of companies producing less than $100 \mathrm{~kg}$ of damaged fish. A large majority of these companies $(72.73 \%)$ claimed to throw away this damaged fish against $27.27 \%$ who still do selling in spite of the poor quality, either directly or in the form of smoked fish.
About $81.82 \%$ of the visited companies were able to value damaged fish against $18.18 \%$ who thought it unnecessary. This was the case of some supermarkets or poor fish shops which at certain moments offer such damaged fish to their staff. Figure 8 gives the frequency of the fate of damaged fish and perception of valuation at the level of the establishments surveyed. 


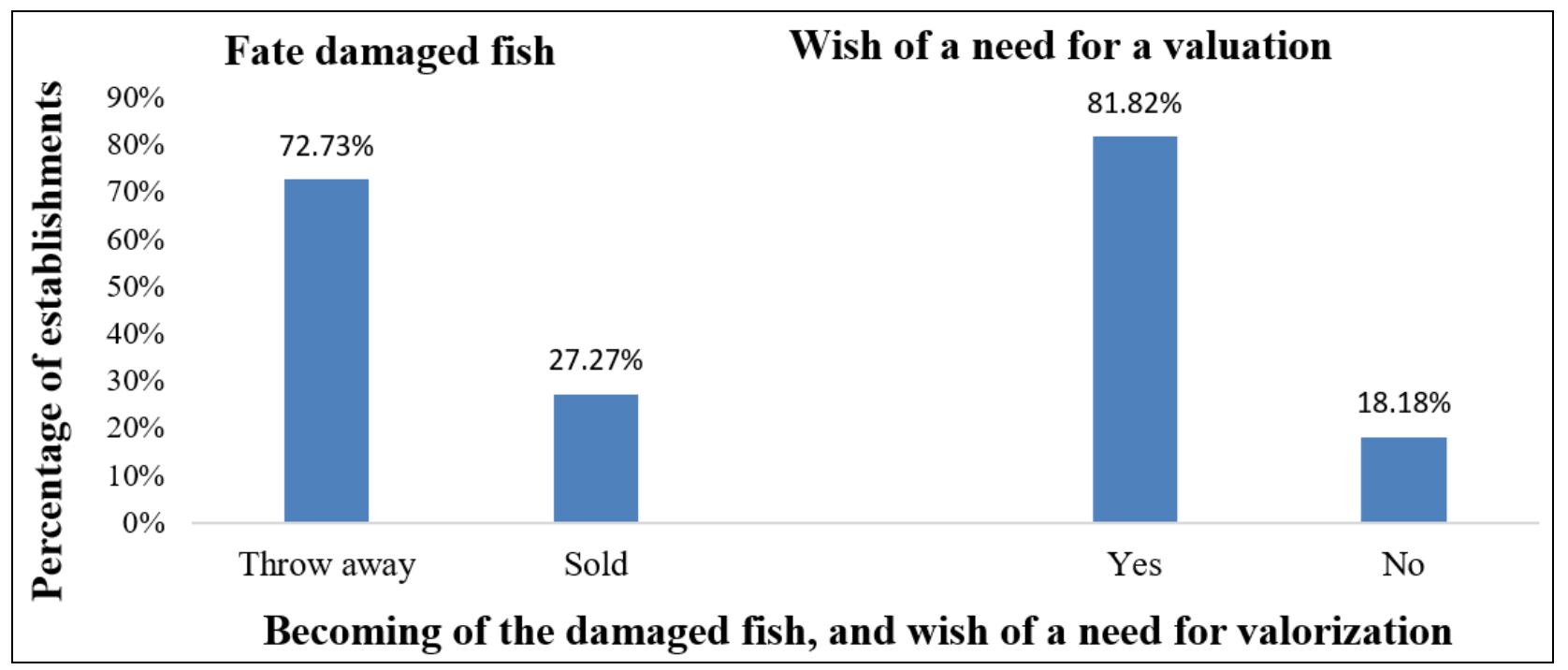

Fig 8: Frequency of fate of damaged fish and perception of valuation at the level of the establishments surveyed.

3.1.1.2.2 Fate of damaged fish

Figure 9 shows that damaged fish had two fates: destruction by MINEPIA sanitary control agents near the warehouses or smoking which is widely used by the majority of fishmongers.

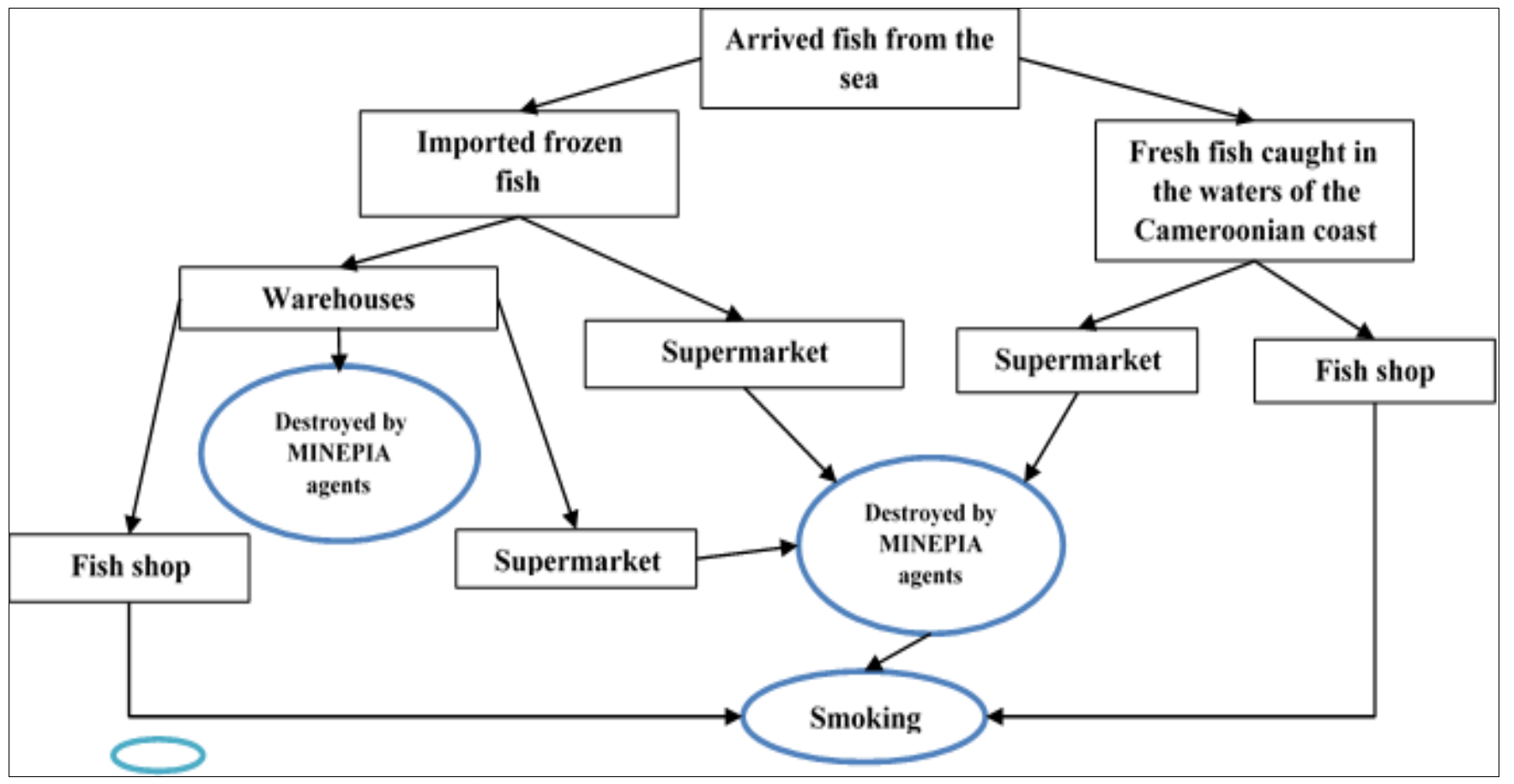

MINEPIA: Ministry of Livestock, Fisheries and Animal Industries

Fig 9: Fate of damaged fish in the markets of Douala

\subsubsection{Chemical analysis of by-products}

By-products collected and analyzed were mainly gills and viscera. The following results were obtained from a powder of the by-products. Table IV shows their macronutrient and micronutrient contents.

Table 4: Chemical composition of fish by-products

\begin{tabular}{|c|c|c|c|c|c|c|c|}
\hline Macronutrients & Moisture & Protein & Fat & Ash & \multicolumn{2}{|c|}{ Total Carbohydrates } & \\
\hline Content (\% DM) & $22.04 \pm 0.03$ & $50.29 \pm 0.02$ & $20.3 \pm 0.03$ & $29.03 \pm 0.15$ & $0.37 \pm 0.15$ & & \\
\hline Macroelements $(\mathrm{g} / \mathrm{kg})$ & $\mathrm{Ca}$ & $\mathrm{Mg}$ & $\mathrm{K}$ & $\mathrm{P}$ & $\mathrm{Na}$ & $\mathrm{Ca} / \mathrm{P}$ & $\mathrm{Na} / \mathrm{K}$ \\
\hline Content & $6.08 \pm 0.002$ & $0.93 \pm 0.0025$ & $1.37 \pm 0.0006$ & $7.093 \pm 0.003$ & $0.351 \pm 0.004$ & 0.857 & 0.256 \\
\hline Microelements $(\mathrm{mg} / \mathrm{kg})$ & $\mathrm{Zn}$ & $\mathrm{Mn}$ & $\mathrm{Cu}$ & $\mathrm{Fe}$ & & & \\
\hline Content & $75.15 \pm 0.02$ & $17.67 \pm 0.02$ & $39.39 \pm 0.03$ & $328 \pm 2.65$ & & & \\
\hline
\end{tabular}

The values presented are means and their standard deviation $\left(\mathrm{x}^{-}, \delta\right) . \mathrm{n}=3$; DM: Dry Matter

They are rich in proteins $(50.29 \pm 0.02 \%)$, followed by ash and lipids respectively. Carbohydrate content was low. Phosphorus was the most abundant mineral (7.093 $\pm 0.003 \%)$ followed by calcium. Sodium content was low. Calcium/phosphorus ratio was high (0.857) and that of sodium/potassium (0.256) was low. Iron content was the 
highest $(328 \pm 2.65 \mathrm{mg} / \mathrm{kg})$ followed by zinc and copper. Table $\mathrm{V}$ shows the values of some chemical indices of the byproducts used in this study. Acid number was high (78.95 \pm
$0.42 \mathrm{mg} \mathrm{KOH} \mathrm{kg}$ of oil) when compared to other indices such as peroxide and anisidine indexes.

Table 5: Values of the indices of the by-products studied

\begin{tabular}{|c|c|c|c|c|c|}
\hline Indices & Pi (mg / kg of oil) & An.i (mg / kg of oil) & TOTOX (mg / kg of oil) & Ai (mg KOH/ kg of oil) & Ii (mg / kg of oil) \\
\hline Content $\mathrm{n}=3$ & $0.79 \pm 0.02$ & $0.52 \pm 0.008$ & $2.10 \pm 0.03$ & $78.95 \pm 0.42$ & $66.83 \pm 1.78$ \\
\hline
\end{tabular}

Pi: Peroxide index

An.i: Anisidine index

TOTOX: Total oxidation index

Ai: Acid index

Ii: Iodine indice

\section{Discussion}

Results showed that fish by-products are released into the market environment of Douala as waste. This waste can be used to fill the gap in the local need of fish for Humans or animals ${ }^{[10]}$. Meat flour from slaughterhouse waste is one of the best sources of protein for domestic animals ${ }^{[11]}$. It is also used in the human diet, and for cosmetics ${ }^{[12]}$. Wastes produced by fish processing are increasingly used in human and animal diets. Animal food and fish flour are mainly being produced using these by-products. Fish flour is the first source of protein used in animal breeding because of its high protein content ${ }^{[13]}$. Producing flour from fish waste is a good example of valorization of fishing by-products. Valorisation of waste has a positive effect on the environment and contributes significantly to fish feeding ${ }^{[14]}$. The main concern is to make the waste a renewable and recoverable resource that can be introduced as much as possible as a secondary raw material in fish feeding ${ }^{[15]}$. This fits with the circular economy which is based on the flow of materials and requires respect of ecological principles and a rational use of natural resources to ensure sustainable development ${ }^{16}$. Damaged fish practically follows two pathways, both of which have consequences. The first pathway is consumers who buy these products in smoked form and can be victims of poisoning, as a result of bacterial toxins ${ }^{[17]}$. The second pathway is linked to importers because destruction of tons of products by the sanitary control agents of the MINEPIA cause serious investment costs ${ }^{[18]}$. Meanwhile, access to such damaged fish is only possible if a valuable treatment method is used. Chemical composition of by-products showed protein content lower than that of commercial fish flour (68 to 70\%) and a greater fat content ( 8 to $11 \%$ and 14 to $16 \%)^{[19]}$. The same results were obtained on the Pseudotolithus senegalensis fillet with a protein content of $66.75 \%$, higher than those of the byproducts ${ }^{[20]}$. By-products of Pseudotolitus typus showed protein $(59.81 \pm 0.17 \%)$ and total carbohydrate $(0.75 \pm$ $0.46 \%$ ) contents higher than those of by-products ${ }^{[21]}$. Protein and carbohydrate contents found are within the range of values defined by Stansby ${ }^{[22]}$ and Love ${ }^{[23]}$, making these byproducts good sources of nutrients for humans. The mean value of the calcium/phosphorus ratio is higher than those found by Ndômbôl ${ }^{[21]}$ and Bayong ${ }^{[24]}$ on the edible part of Polydactilus quadrifilis (Fresh captain $0.150 \pm 0.188$ ), but the values were lower than that found by Nyemb ${ }^{[25]}$ on the edible part of Pseudotolithus typus. The Sodium/Potassium ratio is lower than that of Bayong ${ }^{24}$ on the edible part of Polydactilus quadrifilis (Fresh captain $2.010 \pm 0.000$ ). The contents of iron, magnesium, phosphorus, calcium and zinc found in this study show that these fishery by-products can be a good source of minerals for humans or animals [26]. The zinc content is higher than that obtained by Yanga ${ }^{[27]}$ in the edible parts of some fish from the Cameroon coast including
Pseudotolitus typus (12.4 mg / kg dry weight), Pseudotolitus elongatus $(14.7 \mathrm{mg} / \mathrm{kg}$ and Pseudotolitus senegalensis $(14.8$ $\mathrm{mg} / \mathrm{kg}$ ). But the values were lower than those obtained by Ndômbôl [21] on the by-products of Pseudotolithus typus $(86.15 \pm 6.81 \mathrm{mg} / \mathrm{kg})$. The iron contents show higher values than those of Njinkoue et al. ${ }^{[28]}$ in Pseudotolitus typus (18.9 $\mathrm{mg} / \mathrm{kg}$ dry weight), Pseudotolitus elongatus $(24.0 \mathrm{~m} / \mathrm{kg}$ dry weight) and Pseudotolitus senegalensis (23.7 mg/ kg). Similarly, the calcium content was higher in Pseudotolitus typus (139 mg/kg dry weight), Pseudotolitus elongatus (125 $\mathrm{mg} / \mathrm{kg}$ dry weight) and Pseudotolitus senegalensis $(137 \mathrm{mg} / \mathrm{kg})$ as well as phosphorus in Pseudotolitus elongatus (123 mg/kg) and Pseudotolitus typus $112 \mathrm{mg} / \mathrm{kg}{ }^{[28]}$. The iodine number provides information on the degree of unsaturation in oil and makes it possible to classify nondrying (II <100), semi-drying $(100<$ II < 130) and drying (II> 130) oils. Therefore oils in our by-products would be nondrying. The acid number measures the amount of free fatty acid present in a fatty substance. These results are lower than the standard (4 mg KOH/g) recommended by the Codex Alimentarius ${ }^{[29]}$. This could be explained by a low hydrolytic activity ${ }^{[30]}$. The peroxide number measures the primary oxidation products in an oil. However, this index is only an indicator of the onset of oxidation ${ }^{[31]}$. The higher it is, the more the fat is oxidized. Our results comply with the standard values, which must be less than or equal to 5 milliequivalents. The anisidine number measures the by-products of oil oxidation and takes into account non-volatile aldehyde compounds. The values obtained in our study are lower than that recommended by the Codex Alimentarius [29] which stipulates that for virgin fats and oils, the anisidine index must be less than ${ }^{[20]}$. The total oxidation index gives a better evaluation of the oxidation state of the fat, taking into account the different forms of fatty acid oxidation. The values obtained are lower than those recommended by the Codex Alimentarius, $\leq 26$ oil for virgin fats and oils ${ }^{[29]}$. It is possible to find a high peroxide index in a fat which has not yet shown obvious signs of rancidity such as the smell of rancidity, attributable to volatile aldehyde compounds. Conversely, a low peroxide number does not mean that a fat is not altered. Results show that the iodine number is lower than that obtained on the by-products of P. typus and a higher value for the other indices ${ }^{[21]}$.

\section{Conclusion}

The assessment of fish by-products released into the market environment of Douala shows that certain by-products are valued in these markets. They are rich in macro and micronutrients available for human and animal nutrition. Recovery cannot however significatively reduce the great amount of fish waste thrown each year in the environment of Douala City. 


\section{Acknowledgement}

The authors wish to thank all pre-caterers who provided necessary data for the study.

\section{References}

1. OCDE-FAO. Produits de la pêche et de l'aquaculture. In: Perspectives agricoles de l'OCDE et de la FAO 20112020. OCDE/FAO, Rome, Italie 2011, 171-184.

2. FAO. De la pirogue à l'étal: équipement améliorés de manutention et de transformation pour la pêche artisanale. Document technique sur les pêches et l'Aquaculture 2009, 75.

3. Niang MS, Diadhiou H, Brehmer P. Farine et huile de poissons rappel de notions de base et risques au Senegal. ISBN 978-2-9553602-0-2 Sub-Regional Fisheries Commission / Commission Sous Régionale des Pêches Cover design: AWA (BMBF - IRD) project 2016.

4. Simard F, Gouvello RL. Durabilité des aliments pour le poisson en aquaculture: Réflexions et recommandations sur les aspects technologiques économiques, sociaux et environnementaux. Guide pour le développement durable de l'aquaculture 2017.

5. Ousseynou L. Production de farine de poisson DASP/CRENEAUX PORTEURS Réalisé par ABC Consulting Aly.Sow/CAC Republique du Senegal Ministere de l'Economie et des Finances Direction de l'Appui au Secteur Prive 2014.

6. AOAC (Official Methods of Analysis (15ème edition). Washington DC 1990, 222-245.

7. UIPAC (International Union of Pure and Applied Chemistry). Stantard methods for the analysis of oils, fats and derivates, 6th Edition 1981, 646.

8. AFNOR (Association Française de Normalisation). Recueil des normes françaises. Corps gras, graines oléagineuses, produits dérivés (2ème édition). AFNOR, Paris, France 1981, 438.

9. Shahidi F, Miraliakbari H. Antioxidant activity of minor components of tree nut oils, Food Chemistry 2008;111:421-427.

DOI: http://dx.doi.org/10.1016/j.foodchem.20 08.04.008.

10. Kabahenda MK, Hüsken SMC. Une étude des produits halieutiques de faible valeur commercialisés dans la région du Lac Victoria. Les pêches et le VIH/SIDA en Afrique: investir dans des solutions durables. Fisheries and hiv/aids in africa: investing in sustainable solutions 2009.

11. Meeker DL, Hamilton CR. An overview of the rendering industry. In: Essential rendering. Meeker (Ed). National Renderers Association 2006.

12. Penda E. Contribution à l'étude de la valorisation de protéines d'hydrolysats obtenues par hydrolyse enzymatique des co-produits (tête, viscères) de la Sole tropicale (Cynoglossus senegalensis) au Sénégal,thèse de doctorat en médicine vétérinaire à Dakar, Sénégal 7788, 2007.

13. Nguyen TMH. Valorisation de matières premières marines de faible valeur ajoutée: application aux coproduits de thon, thèse de doctorat, discipline: génie des procédés, spécialité: biotechnologie, université de Nantes ufr sciences et techniques 2009, 23-24.

14. FARNET (Fisheries Areas Network). Farine pour poisson à partir de déchets de poisson FLAG: Huelva Andalousie, Espagne. Résumé du projet. \#018-ES08-FR 2011.

15. Ymelé JP. La voie camerounaise vers une meilleure gestion des déchets. Secteur privé \& Développement. Proparco 2012, 5.

16. Ngambi JR. Déchets solides ménagers dans la ville de Yaoundé (Cameroun) De la gestion linéaire vers une économie circulaire. Mémoire présenté en vue de l'obtention du grade de Docteur de l'Université du Maine sous le label de L'Université Nantes Angers Le Mans. École doctorale: Droit, Economie, Gestion, Environnement, Sociétés et Territoires (DEGEST). Discipline: Géographie Spécialité: Géographie sociale et régionale (CNU 23-24). Unité de recherche: Unité Mixte de Recherche CNRS 6590 Espace et Société (ESO) 2015.

17. MAPAQ (Ministère de l'Agriculture, des Pêcheries et de l'Alimentation du Québec). Guide des bonnes pratiques d'hygiène et de salubrité alimentaires Gouvernement du Québec Dépôt légal: Bibliothèque et Archives nationales du Québec Bibliothèque et Archives Canada ISBN 9782-550-82842-6, 2018.

18. Douffissa A. Recueil des textes régissant l'élevage, les pêches et les industries animales. 2è Edition, réactualisée 2007, 127-129.

19. FAO. State of world fisheries and aquaculture, Rome (Italy) 1998. ISBN 92-5-104187- 3.

20. Nganguem M. Approche physicochimique du pouvoir conservateur du sel: Cas du salage de Pseudotolithus senegalensis. Thèse de Maîtrise Professionnelle de Biotechnologie, Université d'Abomey-Calavi. Cotonou, Niger 2007.

21. Ndômbôl NPR. Valeur nutritionnelle des viscères et branchies issus du nettoyage de Pseudotolithus typus. Mémoire de Maitrise en Production et Valorisation des Ressources Halieutiques. Université de Douala. Douala, Cameroun 2017, 75.

22. Stansby ME. Proximate composition of fish. In: E. Heen and R. Kreuzer (ed.) Fish in Nutrition, Fishing News Books Ltd., London 1962, 55-60.

23. Love RM. The Chemical Biology of Fishes, vol.1. Academic Press 1970, 547.

24. Bayong P. N. Effets de quelques traitements sur la composition nutritionnelle du Polydactilus quadrifilis (capitaine) couramment consommé au Cameroun. Mémoire sciences alimentaires et nutrition 2015, 73.

25. Nyemb GM. Evaluation de la valeur nutritionnelle de Pseudotolithus typus pêché au large des côtes camerounaises et les propriétés hypolipidémiques de son huile chez les rats Wistar mâles dyslipidémiques-thèse 2013, 102.

26. Watanabe T, Verakunpiriya V, Watanabe K, Viswanath K, Satoh S. Feeding trout with no-fish meal diets. Fish Sci 1988;63(2):258-266.

27. Yanga N. Evaluation de la teneur en minéraux de trois espèces de poissons de la famille des Scianidae: Pseudotolithus elongatus, Pseudotolithus typus, Pseudotolithus senegalensis. Thèse de Maitrise en Biochimie. Université de Douala. Douala, Cameroun 2008, 15-26.

28. Njinkoue JM, Gouado I, Tchounbougnang F, Yanga JH, Ngueguim Ndinteh DT, Fodjo CYF et al. Proximate composition, mineral content and fatty acid profile of two marine fisches form cameroonian coast: Pseudotolithus typus (Bleeker, 1863) and Pseudotolithus elongatus (Bowdich, 1825). NFS Journal 4(2016) 27-31. DOI: http://dx.doi.org/10.1016/j.nfs.2016.07.0 02. 2016.

29. Codex Alimentarus. Normes pour les huiles de poissons 
CXS329 2017.

30. Onyeike EN, Omubo-Dede TT. Effect of heat treatment on the proximate composition, energy values, and levels of some toxicants in African yam bean (Sphenostylis stenocarpa) seed varieties. Plant Foods Hum. Nutr 2002;57:223-231

31. Tynek M, Hazuka Z, Pawłowicz R, Dudek M. Changesin the frying medium during deep-frying of food rich in proteins and carbohydrates. J Food Lipids 2001;8:251261. 